\title{
Social Marginalisation of Women in the Saudi Novel after the Gulf War in 1990
}

\author{
Hamad Alhazza
}

\begin{abstract}
Numerous recent studies have examined social subjects of Saudi novels, especially in the aftermath of the Gulf War in 1990, identifying varying social transformations among Saudi society as well as many relevant issues related to human rights, the patriarchal community and women's situation. However, the research has still not examined the social marginalisation of Saudi women in Saudi novels, where many social cases have emerged in the global media during a time when Saudi Arabia ratified the SEDAW agreement in 2000. This paper addresses the theme of socially marginalised women in Saudi novels regarding their right to drive and analyses two different novels that employ different textual strategies and literary techniques when discussing this topic.
\end{abstract}

Index Terms-Saudi women, Saudi novel, women driving, women rights and marginalisation.

\section{INTRODUCTION}

Recently, especially in the last twenty years, there has been clear interest in the concept of "marginalisation" in many fields. Most scholars attribute a negative meaning to the term. Marginalisation is a complex condition of disadvantage as a result of vulnerabilities that might come from unfavourable environmental, cultural, social, political and economic factors. Social marginalisation refers to the position of groups as indicated by the interpersonal or intergroup relationships with one or more groups, and to the attitudes and images, which tend to shape these relationships [1].

Many factors have a deleterious effect on people's lives. For example, people with poor livelihood options (lack of resources, skills and equal opportunities) have restricted participation in public decision-making, less use of public space, a lower sense of community and low self-esteem [2]. Accordingly, the most marginalised regions are in 'developing countries' [3], where marginality primarily manifests itself as a result of spatial disadvantages. In addition, marginality can be exaggerated by "nondemocratic regimes, corrupt officials, dualistic economics, religious Fundamentalism, ethno-linguistic tribalism, and sectarianism" [4]. Therefore, social marginalisation may come from cultural marginalisation where intellectuals, artists, and elites) are feeling that they do not fully enjoy their rights.

In this paper one segment of Saudi marginalised socially will be considered and it is "marginalised women". The analysis of this topic is based on gender equality theory which comprises theories of both gender and feminism.

Manuscript received December 10, 2013; revised January 20, 2014

Hamad Alhazza is with the University of Mnachester, Leeds, UK (e-mail: h.hza@hotmail.com).
There are common elements between the two sets of theories. Also, the analysis is applied on two selected Saudi novels "Al-Riyadh-November 90 by Saàd Al-Dūsarī, and Al-Qārürah (Munira's Bottle) by Yousuf Al-muhameed". These two novels have not been sufficiently employed in the context of social marginalisation of women and they represent the era in aftermath the gulf war in 1990 and the event of women driving at that time. The importance of this era is that the Gulf War produced what could be termed a "culture shock" in Saudi society especially among women who saw foreign women soldiers were driving freely. It created tensions between some Saudi women and their own society and government [5].

\section{LITERATURE REVIEW}

There has been an increase in the number of women writers in Saudi Arabia. These writers use the novel as a means to speak out against social taboos and against the marginalisation of women, which led many segments of society, especially the young, to reading Saudi novels as one of the channels of expression of public opinion and about the marginality women suffer from

Many studies have tried to address and analyse the important subjects in the written novel about woman such as:

Al-Riwāya Al-Nisāyya AL-Sa'ūdiyya: Khiāb Al-Mar'a Wa Tashakkul Al-Sard, (The Saudi Feminine Novel: Woman Discourse and Narrative Formation), by Sāmī Juraidi. ${ }^{1}$ This book discusses the significances of feminine narrative discourse and the social significance of Saudi women's discourse. The author wanted to explain, from the beginning, how to deal with women's marginalisation as a controversial issue in Saudi Arabia in his book where he reveals the real name of his mother in the acknowledgments, where it is considered a taboo/shame the readers/public your mother's name, in many areas in Saudi society.

Ūrat Al-Baal Fì Al-Riwaya Al-Niswìyya Al-Sa'ūdiyya, (The Image of the hero in The Saudi Feminine Novel), by Mansūr Al-Muhawīs. ${ }^{2}$ It is one of the important books in this context because it tries to find more about the opinion of women about the man in women's writing. It examines cultural patterns of the image of men in the feminine novel. It also refers to the cultural awareness of women writers. It also considers the aesthetic composition of man's image by addressing the elements of character, time and place.

In 2009, The literary club in Riyadh published Al-Riwāya Al-Nisāyya Al-Sa'ūdiyya, Qirāa Fī Al-Tārīkh, Wa Al-

\footnotetext{
${ }^{1} 1^{\text {st }}$ ed. Dār Al-Īntishār Al-'Arabī. Beirut. 2008. It consists of 383 pages.

${ }^{2} 1^{\text {st }}$ ed. Mu'assasat Al-Yamāma Al-aafīyya. Riyadh. 2008. It consists of 480 pages.
} 
mawdhū‘, Wa Al-Qadhiyya, Wa Al-Fann, (The Saudi Feminine Novel, Reading in the History, the Theme, the Issue and the Art), by Khālid Al-Rifă' ${ }^{-} 1{ }^{3}$ In this study, the author attempts to address four aspects of the Saudi feminine novel: the history, the theme, the issue of woman in the novel and the genre of the novel. Because this study has addressed all of these aspects, it suffers from some confusion regarding to mixing between the themes and issues For example, he talked about love twice; in the chapter (the emotional novel), and in the separate issue of love in another chapter. Nonetheless, it is considered as a serious attempt to improve the study of literary criticism and to know the reasons behind women's writing in the field of the Saudi feminine novel.

All of these books reflect to which extent critics and academics feel the significance of this topic in following women's needs and images about their situation in Saudi Arabia. The feeling of marginalisation usually leads to the attempt to discover it and explain needs of marginal people especially in a conservative community like Saudi Arabia, which can be considered as being very sensitive when dealing with women-related subjects. Therefore, any writing which is trying to break the taboo deserves to be taken into account in social studies.

Moreover, in 2007, the Dialogue Group ${ }^{4}$ issued Khiāb AlSard, Al-Riwāya Al-Nisāiyya Al-Sa'ūdiyya, (The Narrative Discourse, The Saudi Feminine Novel ${ }^{5}$. It contains a collection of papers which are presented in the "Jeddah cultural literary club" in meetings of some people interested in novels such as academics and novelists. What makes this book more important is the fact that it was an early attempt in Saudi Arabia to analyse the Saudi Novelistic Discourse. However, there are only three papers in this collection which were more related to the topic of social transformations, and these are:

Al-Khiāb Al-Mudhād Fī Riwāyat "Ghadan Sayakūn AlKhamīs, (The Counter-Discourse in the Novel of "Tomorrow, will be Thursday), by Simī Al-Hājirī. He selected an example of the feminine novel and analysed the elements of the novelistic discourse inside it. He also based his study on the hypothesis that women's writing was considered as a challenge to the trend in Saudi Arabia, when she writes against the taboos in the closed society. At the end of his paper, he talked about the experience of women's writing in a patriarchal society and how it becomes different both in the form and the content.

In "Walā 'Al-Khiāb Al-Unthawī Al-ībdā' ̄i Fī Riwāyat Adam Yà Sìdì, (Social Patriarchy of Creative Feminine Discourse in the Novel of "Adam oh Master")", Fāt ima Qāsim addressed two subjects: Social Patriarchy and Literary Patriarchy. She, however, emphasised that there are many Saudi feminine novels which do not tend to be rebellious on the instructions of the patriarchal society.

${ }^{3}$ Originally a M. A. Thesis, it is published by The Literary Club in 2009. Riyadh. It consists of 503 pages.

${ }^{4}$ It is a group of intellectuals and critics. They are interested in cultural and literary issues in Saudi Arabia and most of them are members of a literary club in Jeddah.

${ }^{5} 1^{\text {sted, }}$ Published by Nādī Jiddah Al-Adabī in 2007, Jeddah. It is consists of 694 pages.
Khiāb Al-Īqa Wa Al-Īlāl Fī Al-Riwāya Al-Nisaiyya AlSa'ūdiyya, (The Discourse of Exclusion and Substitution in the Saudi Feminine Novel), by asan $\mathrm{Nu}^{\text {' }} \mathrm{mi}$. This is the most important critical attempt in this context where the author began by talking about the discourse and the difference between it and the content of the novel. Then he talked about giving more significance to the marginalisation instead of the trend in the novel-writing.

\section{Methodology}

The methodology will be based on employing literature as an authentic reflection of controversial and prevalent ideas in the Saudi community regarding women. It is going to be analytical and descriptive at the same time in attempt to reveals the novelist's reasons for writing their novels too.

The practical steps to extract the elements of the two selected novels are performed through a critical reading of the novels' sections that depict social marginalisation, whether these sections are related to the theme or to the technique of the novels and applied as follows:

- Reading and deconstructing novels' texts.

- Looking for images of social marginalisation in the novels' texts.

- Detecting the impact of social marginalisation on the elements of the novels.

\section{SAUdi WOMEN AND THE Right TO DRIVE}

Women in Saudi Arabia are still not legally permitted to drive. It is rare to find someone talking about women without mentioning this. Conservative clerics and "religious puritans who object to the very idea of women are exposed to strangers outside their homes by driving" [6] see this as a step on the road towards westernisation and an erosion of Saudi identity. In contrast, liberal clerics argue that there is no basis for this prohibition and increasing numbers of Saudi men have found ways to demand lifting the ban by signing petitions or even writing to King Abdullah [6]. This topic has not only provoked much public debate but, as our analysis shows, it also proved to be a rich source for novelists wishing to address the subject of marginalisation of women in Saudi society.

Al-Riyadh-November 90 by Saàd Al-Dūsarī and AlQārūrah (Munira's Bottle) by Yūsuf Al-Muhaymīd are novels that mention the ban on women's driving. In addition, throughout this section reference will be made to the book, Al-Sādis Min November 1990: Al-Marah Wa Qīādah AlSayyarah (The Sixth of November 1990: Women and Driving Cars). In this book, A'ā̄shah Al-Māni and iah AlShaykh, two of the 47 participants in the Riyadh protest, recount the events that led up to the protest, their arrest and its aftermath. Al-Māni herself, a businesswoman, claims that the demonstration had a much broader symbolic value. On the fifteenth anniversary of the demonstration in 2005, she stated, "It was never about driving [...] Driving is just a symbol. [...] It's about female empowerment and mobility. Women need incomes, they need jobs, and they need a way to get to those jobs" [7]. 


\section{GENDER Roles In SAUdi Society}

In Saqf Al-Kifāyah, Al-Olwān explores the relationship between males and females in Riyadh and uses a male protagonist, Nāir, to comment on how this urban community make sand enforces a clear differentiation between the sexes, beginning in childhood:

"Sometimes, in Riyadh, they teach us how to be a male before they teach us how to be a human. Our masculinity is fully formed before our humanity. Everybody works hard to teach us this lesson, even females themselves. They bring up their little boys to be real men which will prevent them from playing with girls" [8].

The author uses Nāir's reflections to comment on the relationship between boys and girls in Riyadh society so he can explain why he needed to hide his relationship with the girl he loved. He describes the pervasive effect of society on their life as a couple. The male protagonist and narrator plead with the reader:

"I do not understand how a mother can teach her son to despise those of her own gender without realising her mistake...I have never understood why boys are taught lessons in how to be superior to women rather than to teach both males and females how to complement each other in order to achieve equilibrium" [8].

Thus Al-Olwān argues that Saudi society teaches boysthat all men are better than all women. Munīrah Al-Sāhī, the female protagonist of Munira's Bottle, voices a similar point of view, reflecting on her relationship with the boys and men in her life:

"I am a female, just a female with clipped wings. That is how people see me in my country, a female with no power and no strength. My sole purpose is to receive, like the earth receives the rain and the sunlight and the plough. Supine and recumbent am I, unable to stand erect like a male. I submissively accept all things, even love" [9].

The novelist uses passive terms such as: "recipient", "I'll belong to my teenage son" and "tell me what to do and what not to do", to make the readers sympathise with Munirah, who has been betrayed by her husband Alī Al-Daāl. AlNafjān confirms Munīrah's evaluation of her legal position as a woman in Saudi Arabia:

"Every Saudi woman has a male guardian. At birth, the guardianship is given to her father and then upon marriage to her husband. If a woman is a widow, her guardianship is given to her son-meaning that she would need her own son's permission for the majority of her interactions with the government, including the right to travel abroad" [10].

In her article on women and education in Saudi Arabia, Hamdan notes that until 2001, "Saudi women were considered an extension of their male guardians" [11]. Through Munīrah, Al-Muaymīd echoes the sentiments voiced by the protagonist of Saqf Al-Kifäyah concerning the way in which mothers treat their sons and daughters:

"When I was child, my mother taught me to be wary of strangers, to keep to myself, to store my emotions and energy inside. It was my three brothers whose energies had right to burst forth into the world. Even their genitals moved freely on the outside while mine were tucked inside. This is what my mother taught me in childhood: to keep my emotions and my energy inside me... because only my three brothers are allowed to display their energies" [8].

So, mothers in Saudi Arabia teach their sons and daughters that there is a difference between them. In Banāt Al-Riyadh, Rajā Al-āni describes the result, referring to her male character, 'Son of sheikhs" ${ }^{6}$ : "It is perfectly natural for a man to choose a woman who is inferior to him (especially since all women, in his view, are one level below men in the hierarchy of organisms anyway)" [12]. Men are raised to believe that women's demands for equal rights are not acceptable, especially when the women are the ones making the demands. In addition, longstanding customs and traditions in Saudi society prevent women from claiming their rights. According to tradition, women are forbidden to raise their voices in the presence of men. One researcher describes the situation of Saudi women:

"The women's question in Saudi Arabia is not taboo, at least, not anymore. It has been discussed intensively by public personalities such as certain members of the government, some official and unofficial Ulama, and a number of female and male intellectuals with different orientations" [13].

However, in Lam Aud Abkī, by Zaynab ifn̄̄, ${ }^{7}$ alāl, a male journalist who is in love with the protagonist, is sentenced to jail for six months for daring to write about women's rights. Some novelists portray issues as they see them rather than exactly as they occurred. When people, like oppressed minorities and women, are too afraid of the strong reaction from others towards their claims for equal treatment, they remain at the margins of society. According to some Saudi novelists, that is exactly what has happened to Saudi women. Rajā Al-āni emphasises this point in her description of girls in Riyadh shopping centres:

"Guys stare at women for their own reasons, while women stare at each other just because they are nosy! And they have no excuse for it. A girl cannot stroll about in the malls under the protection of God without being checked out thoroughly by everyone" [12].

In Riyadh, the level of watching each other is higher than elsewhere in Saudi Arabia. Young people are watching each other even though they all make the same mistakes. AlOlwān says in a conversation between Nāir and the girl he loves: "In a city like Riyadh, everyone is watching everyone else, even that frivolous guy was watching us although he messes up".

An atmosphere of this kind ensures that women are kept

\footnotetext{
${ }^{6} \mathrm{He}$ is defined thus by the translator of the novel as: Here, Sheikh refers to the patriarch of an Arabian tribe or family. See: [12] Al-Sani R. Girls of Riyadh. London: Penguin books, 2008. 265

ifnī was prevented from travelling and writing in the press after publishing her 1996 novel "Nisaa' 'Alā Khaț Al-'Istiwā'”" (Women on the Equator) which frankly addresses issues of sex, love, and women rights. ifnī talks about this work in an interview for Iḍâ'āt programme on $\mathrm{Al}$ Arabiyah Channel which was uploaded onto YouTube in 2011: http://www.youtube.com/watch?v=Ox8_SyyyJlk\&list=PL22F32B69D68F $\mathrm{C} 72 \mathrm{C}$
} 
at the margins, attempting to keep far away from those locations (Malls for example) that community traditions consider suspicious. Later in the novel, Nāir engages in an internal monologue with his girlfriend about the bag which she had given him as a present: "How many curses of this city [Riyadh] would pour down on you if this bag was made available to be opened by everybody?" [8].

This reflects the extent to which Saudi women are not allowed to have a personal life in public spaces. The problems of Saudi women are more likely to be expressed in novels than in media. Saudi women are in the best position to protest the restrictions that are imposed on them. However, some male Saudi novelists have exposed the problems faced to Saudi women. Usually, insider's writers are better at expressing their opinions about women's situation in their communities but they may not have the freedom to talk about that outsiders do. So, they are more able to express Saudi women, but they do not have the freedom of those who are living abroad. Michelle, one of the five female characters in Girls of Riyadh, consults an Egyptian psychiatrist after being abandoned by her boyfriend Faisal. After four visits without results, she comments:

"How could a male Egyptian shrink understand the dimensions of a problem that afflicted her female Saudi self anyway, with the enormous gap in social background that their nationalities entailed, since Saudi Arabia has a unique social setting that makes its people unlike any others?" [12].

Thus, the difference between Saudi Arabia and Egypt makes it difficult for non-Saudis to understand Saudi women. In "What do Saudi Women Want?" Eman AlNafjan claims that "Saudi Arabia may be even more conservative than most outsiders think. There are some who are not only passively happy with the status quo but also loud in their resistance to any form of change" [10]. Thus, many people who criticise the treatment of Saudi Arabian women will be accused of opposing government policies. This idea is discussed in Al-Riyadh-November 90 by AlDūsarī in the context of women driving [14]. Believing that they are unable to debate the restrictions on Saudi women in the Kingdom's official press, Saudi writers have resorted to the novel. In their fiction, they are also able to explain why they could not express their opinions in the press. A scene in Al-Dūsarī's novel features a phone conversation between his male protagonist and a girl from a conservative family. Since he is the editor of a magazine (Its name is not mentioned), she asks, "Shouldn't you deal with some controversial issues relating to Saudi women instead of what you usually discuss in your magazine?" He answers.

"I agree with you, but we have a list of subjects which no one can talk about". Then she replies: "That is because they all focus on women" [14].

That girl tries to find a logical explanation that prevents women from claiming their rights. At the same time, she could not discuss it with her family. Thus, in this conversation, it is highlighted that the main reason for preventing the discussion of Saudi women's rights is not because it does not comply with the teachings of Islam, but because it revolves around "judging women on the basis of their gender".

This could lead to misogyny. According to D Jonte-Pace, claims that Freud is seen as a misogynist thinker from his critical feminist perspective because he claims that women have are straining influence on civilisation [14]. Islam has traditionally rejected the abuse and oppression of women, and stands in opposition to many misogynistic Arabic traditions. For example, Islam prohibits Wad Al-Banāt (female infanticide). Before Islam, fathers were killing their daughters as they believe that girls usually bring the shame to the family so they kill them for the honour of the family, unlike boys who bring the pride to their fathers. Both are forms of misogyny. This type of an extreme discrimination against women, Wad Al-Banāt (female infanticide), is not found in Saudi society now but it can be a background of any impression about Arabic women especially when women are deprived of rights or privileges such as driving for reasons that have nothing to do with religion. It can be said that the misogynist thoughts were found in Arabic culture not in Islam teachings, based on the subject of Wad AlBanāt (female infanticide).

\section{NOVEMBER 6 1990: THE DRIVING DEMONSTRATION}

This section begins by analysing the Al-Dūsarī's work AlRiyadh-November 90. He began the novel at the end of 1991, in response to the Gulf War:

"I was thinking about recording the events of the important historical stage which we lived in before and after Iraq's invasion of Kuwait. It was a significant turning point in history, on both a local and an international level. Every writer in the world must have thought about writing about it or actually did" [15].

Al-Dūsarī confirmed that the majority of the people who bought his work at the Book Fair in Riyadh in 2012 were young Saudis (males and females), perhaps because his novel is a depiction of that historic moment[15] and a commentary on the social issues that emerged, including women's right to drive. Although Al-Dūsarī's novel was banned for twenty years until 2011. Al-Dūsarī was asked about the reasons for preventing his novel, he answered: "I have no idea. You can ask the question to the agencies that I have dealt with". In 2012 it won the most prestigious literary prize offered by the Ministry of Culture in Saudi Arabia [15]. This fact in itself shows that many social transformations have occurred in the Saudi society at all levels, including both public and official These social transformations have meant that Al-Dūsarī's novel was finally able to be read. The Saudi literary critic Abdūllah Al-Ghadhāmī commented on the significance of this novel:

"Saa'd Al-Dūsarì wrote this novel twenty years ago. It offers detailed coverage of events within society. However, Saa'd did not dare to spread it, since all his friends advised him not to do this. It was passed from person to person by making copies of it and giving these to each other as a gift, making it the most famous unpublished novel in Arabic. If it had been published at that time, it would have created a 
major debate because indeed it was the first novel to address taboos in depth.8“

The novel gives the impression that the protagonist is member of Saudi's educated elite. The novel's first-person narrator remains nameless although it has been proposed that the majority of Saudi novels are autobiographical. In the opening scene, the hero searches his library for a famous Mexican novel. Sometimes, the author describes the details of the protagonist's daily life, sitting in the living room, reading the newspapers, watching television and conversing with his wife and his mother about the war. The protagonist is a medical assistant in a hospital, where he encounters Saudis of all classes and backgrounds. Al-Dūsarī also describes the relationship between the hero of the story and his wife's cynical teenage brother, typical of many young Saudis who do not care about the future. Al-Dūsarī thus presents many topics, including that of women driving, from many points of view. The author deliberately uses the word "مظاهرة" (demonstration), which is how most Saudis saw it. He also implies that the event was spontaneous [14]. However, Al-Māni and Al-Shaykh describe in their memoir three planning meetings. The first was held in October 1990, when Noura Al-Ghanem and her sister Sarah visited Dr AlShaykh in her office. The second was held in the home of Noura Al-Ghanem on October 24, 1990, when a group of women wrote a letter to Salman Bin Abdul Aziz, Prince of Riyadh, demanding their right to drive, among others. At the final meeting on November 5, 1990 at Nadia Al-Abdali's house, the women decided that the next day they would drive through the streets of Riyadh [16]. Al-Dūsarī uses Munīrah to explain the extent to which the drive had been planned:

"Forty girls and women agreed to meet each other this afternoon in front of the Fāl shopping centre in ala Al-Dīn Street. They drove their husbands' and brothers' cars from there towards Al-Orübah Street. Now, they have been detained for investigation in Al-'Olayyā police” [14].

In this passage, the word "|تفقت" (agreed) gives an indication that they were planning this. The narrator has his character give places and times, of the event although according to Al-Māni and Al-Shaykh, it took place in another location. Following this episode, Al-Dūsarī describes an interview with a girl who, like many other young women wants to become a volunteer at the hospital when the war begins. Nurse objects, insisting that the girl is that she is weak: "Doctor, would you believe that she came to the interview with two of her servants?" [14]. This is the view of the majority of Saudi society about women at that time (even women themselves); so many women activists try to raise the level of awareness among women of their rights. For example, Manal Al-Shareef usually confirms this point in her interviews and presentations. ${ }^{9}$ They believe that Saudi women need help with everything, including driving.

The novel then shifts to the scene of the women protesters

\footnotetext{
${ }^{8}$ Unless otherwise indicated, all translations are the researcher's own

${ }^{9}$ She is a womens' rights activist who called for start driving in 2011 and used Facebook for her demands. See her presentation about her attempts to raise awareness of women in Saudi Arabia of their rights in TEDTalks, [17] Al-Shareef M. Manal al-Sharif: A Saudi woman who dared to drive. TEDTalks; 2013.
}

who had been detained by the police. One girl was showing them how to answer the questions they could expect during interrogation:

"When he asks you: "Who arranged this demonstration?" say, "Nobody. We met each other by accident and we found ourselves driving the cars." Don't be scared. He is going to threaten you. He is going to threaten you with imprisonment. Don't be frightened. They will not be able to put us in prison'" [14].

This unnamed girl reminds the protesters that they have not broken any rules and explains why they have the right to drive: "We did not commit a moral crime. We have international driving licenses. There is no formal rule preventing Saudi women from driving [14]. Al-Māni and Al-Shaykh claim that those who took part in the driving protest were not afraid of the police, but of the Commission for the Promotion of Virtue and the Prevention of Vice. They had heard many frightening stories about how the organisation treated people accused of committing moral violations [16]. The author narrates a conversation between two young men in the waiting room at the hospital after the protest. One of them describes what he had seen:

When armed policemen surrounded them they got out of their cars and raised their hands. One of them tore off her Abaya and trampled on it. Another girl talked to an American photographer who was filming the demonstration. Her long hair was falling loose onto her dress which was tight-fitting and open up to the knee. She said: 'We want to be free'. Then she raised her hand with a sign of victory. After that, the policeman put his hand over the photographer's camera and then pushed him away [14].

The protesters, according to the witness, did not respect Saudi traditions or Islamic obligations concerning Awrah and khalwah. Two of the drivers have defied the Saudi dress code. Even worse, they do so in the presence of a nonmahram male who is taking photographs. In keeping with Al-Dūsarī's narrative technique, he has the other character ask him about it:

The other young man asked, "So you were there?! No, the person who told me this story was driving his car behind the girls and he saw everything".

Many of the accounts of the protest were second- and third-hand gossip and rumour, not eyewitness reports. In another scene, Al-Dūsarī comments on another discussion of the protest:

"They were not discussing the demonstration as a social or political event. Their interest was in knowing the girls' names. Were they belonging to tribes or were they nontribal (Khaīrī)?! 10 Were they beautiful or ugly girls?! Someone said: 'If they were beautiful women with high family connections, the police would not have arrested them ", [14].

As Anthony notes: “Despite a half-century's official campaign against tribalism in the name of encouraging national and Islamic solidarity, clan and lineage remain a

\footnotetext{
${ }^{10}$ In some areas such Najd area, (Khaīrī) refers to person who is not a member of a tribe.
} 
potent force in Saudi Arabian society". ${ }^{11}$ The author suggests the extent that people slandered the women who participated in the event. Al-Dūsarī has several characters describe what had happened:

"I have tried to explain that I and my wife were in ala AlDin Street and I saw them veiled. None of them were showing any part of their hair. He replies that his friend saw some of them uncover their faces and they are ugly" [14].

Once again, an eyewitness account is juxtaposed against an anonymous one. In addition to documenting the range of reactions to the protest, Al-Dūsarī encourages the reader to reflect on the veracity of the accounts that were circulating at the time. According to Rosnow and Foster, rumours function as "public communications that are infused with private hypotheses about how the world works [...] or more specifically, ways of making sense to help us cope with our anxieties and uncertainties" [18]. By reproducing these rumours, Al-Dūsarī reveals the latent fear of changein Saudi society.

In Al-Qārūrah (Munira's Bottle), Yūsuf Al-Muhaymīd describes the events of November $6^{\text {th }} 1990$ from the perspective of his female protagonist, Munīrah Al-Sāhī. The characters have their own responses, but Al-Muhaymīd seems sympathetic to his protagonist where he speaks through her. Actually, this is not the narrator's job to give his own opinion and try to convince others of his opinion. In chapter thirteen of his novel, he takes the role of the lawyer in this case. That what makes Saudi novel, in general, does not affect public opinion as much as the others in some countries. In Al-Qārūrah (Munira's Bottle), the reader is going to feel that Al-Muhaymīd could not make difference between his personal opinion and the reality. This is why many critics believe that early Saudi novelists could not put clear boundaries between the novel and the article. A passage from Al-Qārūrah (Munira's Bottle), by AlMuhaymīd describes the event fromone point of view:

"At the next lights the first-ever procession of cars driven by women in this desert city comes to a halt when a traffic policeman, who has just turned out of Aruba street, signal to them to stop. A university professor winds down the window of her Chevrolet to speak to him. She is wearing a niqab, and all that is visible of her face are two nervous eyes. Clearly shaken, the policeman looks at her and asks her for her driving license. She takes out an international driving license she obtained when she was studying in America... He has no idea what to do. The women are driving well; they are dressed modestly, and they have not broken any traffic regulations" [9].

In Al-Qārürah (Munira's Bottle), the story of the protest

\footnotetext{
${ }^{11}$ Anthony, John Duke 1982 "Saudi Arabia: from Tribal Society to nation-state" In Saudi Arabia: Energy, developmental Planning, and Industrialization R El Mallakh and Dorothea H. El Mallakh (eds) International research centre for Energy and Economic development Lexington, Mass.: D C Heath Available online: ncusar.org/publications/publications/1982-27-01-Saudi-Arabia.pdf It is interesting to note in this context Al-Shaikh's own experience. When she revealed to her father that she had participated in the protest, he was angry and concerned not only about the reaction of Saudi society but that of their tribe. Sometime later, at a tribal meeting, it was decided that due to her actions Al-Shaykh was no longer to be considered as one of the tribe.
}

is told without interruption by a single source, perhaps because that the author was sympathetic to the women. AlMuhaymīd's version, like that of Al-Dūsarī, is laden with symbolism. The author begins by referring to Riyadh as Add Arabic word (a desert city), a curious description for the capital of Saudi Arabia. The very name of the city is originally derives from the Arabic rawdah, meaning gardens or meadows, and refers to the fact that it is located at the juncture of two Wadis which make it a naturally fertile location. However, the term 'desert' has numerous negative connotations as a harsh, primal environment. Perhaps, AlMuhaymīd wished to evoke these negative images in reference to the difficult lives of women in this city. It is interesting to note that this link between Riyadh and the desert is made in another contemporary Saudi novel. Muhammad Al-Muzain̄̄ writing in Mafāriq Al-Atamah [19] 8) emphasises the geographical location of the Saudi capital as an Arabian Peninsula city which travellers must approach by desert:

"There, where the tired city lies surrounded by sand on all four sides [...] that was my city (Riyadh) and I was living in a part of it".

Also, [8]: 12) describes Riyadh as a huge spaceship which landed on the desert a hundred years ago and has still not moved.

According to the narrator in Al-Qārürah (Munira's Bottle), the details are indicative of class and status. The woman who is stopped is driving a Chevrolet, a luxury car. She is an academic who has studied in the United States, and is therefore a member of the educated upper class. Scoring to Al-Māni and Al-Shaykh, the protesters were members of Riyadh's elite [16]. By stressing that the majority of the women are educated and have been studying abroad, the author also perhaps suggests that they participated in this act consciously.

In this description, emphasis is placed on the female protester's appropriate clothing. She is veiled. The other women are wearing modest clothes. There is no evidence of rebellion, or disrespect for the status quo. The first protester is described as قلقتين (nervous), and when asked, she provides an international driver's license. All of the women are said to be complying with all traffic laws. The final comment, therefore, proves that as drivers, at least, these women pose no threat. The other theme which emerges here is that of Westernisation as a positive force. The protester is driving an American car, with a permit issued in the United States, where she presumably learned to drive. Having been educated in the United States, this woman might also have been influenced by American ideas about the role of women in society and is willing to struggle to obtain these rights in her own country. Someone can ask: Is not it just as likely that the fact that her family sent her to study in the US means that she had acquired this sense of empowerment from her parents in Saudi Arabia? Do families who wish to keep their daughters in "traditional" roles send them to study in Western countries where they can get exposed to ideas that are objectionable? Actually, those families do not mind to send their daughters for education but not for having Western ideas and that is not applicable. 


\section{Conclusion}

This paper has focused on the issue of social marginalisation of Saudi women in the public spheres. It has examined how women are right to drive and have been depicted by Saudi male and female novelists. Different textual strategies and literary techniques used by these novelists were analysed when they wrote about the social reality of Saudi women's lives.

The analysis of these works suggests that when writing about the protest in Riyadh on November 6, 1990, novelists used a range of strategies. Al-Dūsarī has his male narrator present a multiplicity of voices expressing the diverse reactions to the protest within Saudi society, without taking a stand. Al-Muhaymīd, in contrast, uses his female narrator to take a position so he spoke through his character.

In depicting the marginalisation of Saudi women, novelists imply that the obstacles and difficulties which they document are not attributable to Islamic teachings but to the imposition of tribal customs and traditions. This explains why Saudi women writers cite Islamic teachings in demanding the rights which their faith grants them, but that tribal traditions have taken away.

\section{ACKNOWLEDGMENT}

This work was supported in part by the Al Imam Mohammad Ibn Saud Islamic University (IMSIU).

\section{REFERENCES}

[1] N. P. G. Phylon, Cultural Versus Social Marginality: The AngloIndian Case, Published by Clark Atlanta University, vol. 28, no. 4, pp. 361-375, 1967.

[2] P. Brodwin, "Marginality and cultural intimacy in a transnational Haitian community," Citeseer, no. 91, 2001.

[3] W. Leimgruber, Between Global and Local: Marginality and Marginal Regions in the Context of Globalization and Deregulation, Ashgate Publishing, Aldershot, Hants, England, 2004.

[4] A. Mehretu, B. W. Pigozzi, and L. M. Sommers, "Towards typologies of socio-economic marginality: North/South Comparisons," Theoretical and Methodological Aspects of Cultural, Social and Economical Parameters of Marginal and Critical Regions, vol. 82, no. 2, pp. 89-101, 1999.

[5] D. Champion, The Paradoxical Kingdom: Saudi Arabia and the Momentum of Reform, Columbia University Press, 2003.

[6] S. Shmuluvitz, "The Saudi women2drive campaign: just another protest in the Arab Spring?" Tel Aviv Notes, vol. 5, no. 14, 2011.

[7] F. S. Ambah, "Saudi women recall a day of driving," The Christian Science Monitor, pp. 158-159, 2005

[8] O. M. S. A. Kifāyah, 1 ed., Beirut, Dar Al-Farabi, 2004.

[9] Y. A. Mohaimeed, Muniras Bottle, Amer Univ in Cairo Press, 2004

[10] İ. A. Nafjān, "What do Saudi women want?" Foreign Policy, vol. 28, 2011.

[11] A. Hamdan, "Women and education in Saudi Arabia: Challenges and achievements," International Education Journal, 2005, vol. 6, no. 1, pp. 42-64.

[12] R. Alsanea, Girls of Riyadh, Penguin books, 2008.

[13] A. L. Renard, "Only for women: women, the state, and reform in Saudi Arabia," The Middle East Journal, 2008, vol. 62, no. 4, pp. 610-629.

[14] A. D. Sd, Al-Riyadh-November 90, Beirut: Al-Markaz Al-Thaqafi AlArabi, 2012.

[15] A. D. Sd, Anfaqtu TharwatīAlā, Al-Riyadh November 1990.

[16] A. M. Aa and A. Shaykh, Woman and Driving the Car 1990, 1 ed. Beirut-Lebanon, Jadawel, 2013.

[17] A. S. M. M. A. Sharif, A Saudi Woman who Dared to Drive, TED Talks, 2013.

[18] R. L. Rosnow and F. G. Alan, Rumor and Gossip: The Social Psychology of Hearsay, New York: Elsevier, 1976.

[19] M. A. Muzayn̄̄, Mafāriq Al-Atamah, Beirut: The Arab Institute for Research and Publishing, 2004.

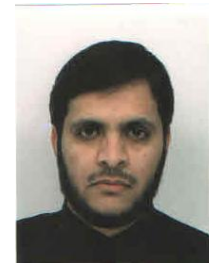

novel.
Hamad Alhazza was born in al-Hawtah, Saudi Arabia, in 1980. He has received the B.A in Arabic language (Imam University in Riyadh), and the M.A in the modern Arabic literature (King Saud University in Riyadh). Currently, he is doing his Ph.D. at the University of Manchester in the UK in the field of Arabic novel. His major interest is in Arabic novel, social marginalization and feminism. He has published a book in the Saudi novel in 2013 related to the Saudi 